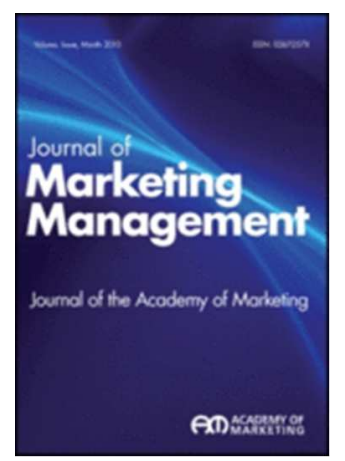

\title{
Rev Billy vs. the Market: A sane man in a world of omnipotent fantasies
}

\begin{tabular}{|r|l|}
\hline Journal: & Journal of Marketing Management \\
\hline Manuscript ID: & Draft \\
\hline Manuscript Type: & Special Issue Article \\
\hline Keywords (headings not \\
selectable): & $\begin{array}{l}\text { Power relations < Contemporary perspectives in marketing, Green } \\
\text { marketing < Sustainability, Corporate Social Responsibility (CSR), ethics < } \\
\text { Sustainability }\end{array}$ \\
\hline Methodologies: & Interdisciplinary/Multidisciplinary research \\
\hline Free Response Keywords: & omnipotent fantasies, will to power \\
\hline
\end{tabular}

\section{SCHOLARONE ${ }^{\text {TW }}$ \\ Manuscripts}




\title{
Rev Billy vs. the Market: A sane man in a world of omnipotent fantasies
}

Journal of Marketing Management, 'Sustainable consumption: Activism, innovation and brands' special issue

\begin{abstract}
This paper presents a case study of anti-consumerism activist William Talen, aka Reverend Billy, who founded the Church of Stop Shopping. Rev Billy's radical critique of the worship of markets and money complements his creation of a vibrant Earth-loving community. The case is reviewed in light of Nietzsche's vision of 'the madman in the marketplace'. The analysis suggests that the dream of an infinitely-expanding world market is a fantasy of omnipotence that acts as maladaptive defence against feelings of powerlessness. This fantasy of market omnipotence is in practice endangering human existence. Rev Billy teaches us to rediscover our reverence for the Earth, and set ecological sustainability as our supreme goal (rather than financial growth).

Summary statement of contribution

Progress requires resisting fantasies of omnipotence, and directing our will to ecological sustainability.
\end{abstract}

Keywords: sustainable consumption, market, omnipotent fantasy, will to power, spirituality, psychodynamics 


\section{The revelation of Rev Billy}

An economic system centred on the god of money needs to plunder nature to sustain the frenetic rhythm of consumption that is inherent to it. The system continues unchanged, since what dominates are the dynamics of an economy and a finance that are lacking in ethics. It is no longer man who commands, but money. Cash commands. (Pope Francis quoted in Vidal, 2014).

We're lost. Finally we get down to the point where we look around and we wonder 'Where did the consumers go? Where's my market, where are my customers?' The consumers consumed the consumers! The consumption of consumers by consumers has consumed the consumers. There's no consumer society because the consumers consumed the consumers consuming the consumption. (Talen, 2012)

This paper presents a case study of green activist Reverend Billy, founder of the Church of Stop Shopping and alter-ego of actor William Talen. For decades Rev Billy has used tragicomedy to critique the icons of consumerism and the worship of capital. The case is analysed from an interdisciplinary perspective, as called for by McDonagh and Prothero (2014), who ask an intriguing question: 'we are curious as to how we can begin to understand why we engage in unsustainable behaviours when so many of us realise that these behaviours are not sustainable?' (p. 1196), even though 'humanity itself is endangered' (p. 1186).

This essay finds an answer to this question in what Butler (1997) calls 'the psychic life of power'. A psychodynamic approach is adopted to understand the role of power in the globally-interconnected marketplace. The specific research question addressed is: What do the psychodynamics of power reveal about how to unblock the transition to sustainability? The interdisciplinary literature review in the following section addresses Rev Billy's charge that our financial operating system is psychopathic because relentless pursuit of growth of a physical system on a finite planet is ecocidal and suicidal (Bakan, 2005; Billy, 2012; Daly, 2014; Hansen, 2009; Higgins, 2010; Sievers, 1999).

Diverse theorists explain the ecocidal trajectory of the globalized marketplace as the expression of a desire for omnipotence that emerges from irrational fears of powerlessness (Becker, 1997; Morante, 2010; Searles, 1972; Wink, 1986). Unconscious terror of impotence spurs a desire for (or will to) power, which no quantum of real power can satisfy. People, organizations and the global village itself thus indulge in fantasies of omnipotence, which 
play a central role in 'normal' human worldviews and culture (de Vries, 1991; Dodds, 2011; Ellman \& Reppen, 1997; Ferenczi, 1925; Searles, 1972).

The various strands of academic literature on this issue stem from Nietzsche. The core theme of Nietzsche's thought was the will to power, his description (inter alia) of the human tendency to become addicted to power and to retreat into fantasies of omnipotence (Freund \& Jacobi, 2013; Kaufmann, 1974; Nietzsche, 1968, 1969). This essay compares Rev Billy to Nietzsche's vision of 'the madman in the marketplace' - a crucial (but overlooked) image in the history of market thinking. Nietzsche's allegorical scene personifies the historical moment when collective fantasies of omnipotence began to be projected into the Earthly marketplace, rather than 'above the canopy of stars' (Schiller, 1785).

Nietzsche's marketplace prophet Zarathustra and Rev Billy are in various ways saner than the normality they confront - especially by urging us to resist fantasies of omnipotence and appreciate the beauty of living on Earth. The experimental science of Terror Management Theory (Arndt \& Vess, 2008) supports Rev Billy and Zarathustra's contention that fears of powerlessness - especially in the form of personal death and human extinction - make us wish to transcend reality, overcome our reliance on our mortal bodies, and isolate ourselves from the dangers of living on Earth (Becker, 1997; Billy, 2006, pp. 56, 61, 67; Nietzsche, 1969, pp. 60-64).

Unfortunately, omnipotent fantasies (e.g. immortality ideologies) through which we try to deny and overpower the realities of Earthbound being often make that which is feared more likely to occur (Dickinson, 2009; Koole \& Van den Berg, 2005; Latour, 2013; Rank, 2002; Sheets-Johnstone, 2003). For example, as the planet heats and the threat of human extinction grows, we try to save ourselves by growing an economy based on fossil fuels, leading to the possibility of 'runaway' atmospheric warming (Hamilton, 2010; Hansen, 2009).

Infinite expansion of financial and consumer markets is not a rational goal on a finite, changeable and sensitive Earth (Beddoe et al., 2009; Fisk, 1973; Hubbert, 1993). Collective belief in the saving power of growth is mad if that means an un-moral financial operating system programs the industrial machine increasingly to convert the living Earth into capital (Heinberg, 2007; Hornborg, 1992).

By contrast, thinkers such as Thich Nhat Hanh (2013) describe how we exist (or inter-are) within Earth's living body, bathed in the energy of the sun, as part of an evolving cosmos. In 
light of this, the idea of a human economy that is independent of the living Earth is seen as a delusion (Ryland, 2000; Schumacher, 2011). Our most urgent task is therefore to reprogramme the global financial operating system to reward activities that reduce (rather than exacerbate) ecological disruption, waste and pollution (Daly, 2014; Goodchild, 2012; Rifkin \& Howard, 1980).

The conclusion of the paper is that we need to re-direct our collective will away from fantasies of salvation by an ever-expanding world market or by omnipotent technology, and focus instead on collective self-restraint, and on building a cultural economy focussed on reverence for the living planet that sustains us (Roszak, Gomes, \& Kanner, 1995).

Sherry's (2000, p. 328) description of the revelation of our dependence on Earth evokes the visceral and all-embracing nature of the challenge: 'Political and philosophical regimes of environmental reclamation and redemption must be mobilized by conversion experiences in the individual's soul'. Or as Reverend Billy puts it: 'Pulling out of the advertising/debt/waste cycle of Consumerism is our idea of deliverance' (Billy, 2006, p. 23).

\section{The Market as God}

The corporations study us from their surveillance cameras and they see that we still remember this thing called Earth. Sometimes our suspicions are aroused. Was that fire supposed to be the size of France? [...] Each of us is absorbing this tragedy personally. It is the best-kept Apocalypse. Yes, I'm crazy. My city is crazy. My species is crazy. (Billy, 2012, p. 34)

This section analyses the psychic life of power in the global marketplace, advertising, brands, profit-driven banks, central banks, financial markets, growth and capital. It thus traces our susceptibility to fantasies of omnipotence in interwoven 'material' and 'spiritual' realms. Sherry (2001, p. 58) proposes that, 'If marketing is to help redress the psychological, social, and cultural grievances of the ecological catastrophe it is conspiring to provoke, marcologists must devote their attention to cosmography':

Humans have a cybernetic, field-like self. [...] Ultimately, we seek identification and merger with the ecosphere [...] an expansive sense of self that transcends the "egoic, biographical or personal" [...] The ecotheism I envision is [...] an invitation to the direct experience of immanence in the service of transcendence, of interconnection with and interdependence upon nature, of holistic and 
holographic involvement with the universe [...] we might well look for inspiration to the Buddhist, Hindu and animist traditions' (Sherry, 2000, p. 332).

Sherry (2001, p. 60) also lobbies for 'ecotheism celebrating hylozoic animism', and observes that: 'A properly turned mythology, and its enactment in ritual, will compel sustainability, just as assuredly as it has heretofore impeded it' (2013, p. 214).

This essay analyses the role of power in Sherry's psycho-cultural diagnosis and prescription, and uses this analysis to address the research question. Sherry's proposed counter-narrative may combine revelation of human dependence on Gaia; reverence for the living Earth; Buddha-like aversion to the addictive qualities of power (Hanh, 2008; Mascaró, 2004); and unity of personal and cosmic being (Wilber, 1996). Such a revitalizing story will enable us to realise our longing for sustainable modes of living; to appreciate being-here; and help us to see through cultural fantasies of omnipotence of a Kronos-like Market (Jung, 1966; Taylor, 2010).

In animist traditions, vulnerable humans worshipped the powers of the living Earth (Freud, 1999; Harvey, 2006; Rust, 2008). The literature reviewed below suggests that as our power multiplied exponentially through the development of symbolic and physical tool systems, we increasingly lost touch with the reality of Earth, sun and cosmos, and retreated into cultural fantasies of omnipotence in which anything is possible (Becker, 1997; Lothane, 1997; Morante, 2010).

Our fear-driven thirst for self-delusion has at last brought us to the 'Anthropocene' - a historical nightmare in which we have become the dominant geophysical force on Earth. We have become the tools of a financial operating system that is systematically consuming Gaia, powered by vast stores of hydrocarbon energy (Chakrabarty, 2009; Crist, 2013; Ryland, 2000; Stutz, 2010). So 'successful' are we in pursuit of ever-more power that we are in danger of the ultimate pyrrhic victory - ecocide (Higgins, 2010), as described by Searles:

Our frustration at the knowledge that we are merely mortal is vastly intensified by the knowledge that we have created a technology which, seemingly omnipotent and immortal itself, has not extended our only alloted life span much [...] So we identify unconsciously with this technology which, being inanimate, cannot die. We find assurance that in its versatile devouring it has grown ever more powerful as it has leapt from feeding upon coal [...] to oil [...] to uranium. We find reason to hope that $[\ldots]$ atomic or some still more magical power will have enabled immortal technology to leave this ravaged planet behind [...] In this realm of 
omnipotent fantasy, in fact, mother earth is equivalent to all of reality, which is a drag and hinderance to our yearnings for unfettered omnipotence, and we want to be rid of it (1972, p. 371).

Ferenczi (1925) describes the developmental basis for this conflict between physical reality and unacknowledged fantasies of omnipotence. He characterises the unconscious mental life of a healthy foetus in the womb as a period of 'unconditional omnipotence'. The unborn being is supplied with nutrients, feels entirely safe, existing in a calm, stable, living world where she wants for nothing. As an independent physical being, the foetus is utterly powerless; but in psychic terms, the foetus is the cosmos - she is all-Being, not separate (Wilber, 1996).

After the trauma of birth, this peaceful, unconscious, oceanic 'paradise' is lost. The baby enters a period of 'magical-hallucinatory omnipotence' and learns to use cries and gestures to communicate and try to control her environment. Ferenczi concludes that the 'almost incurable megalomania of mankind' (p. 121) stems from the fact that: 'All children live in the happy delusion of omnipotence, which at some time or other - even if only in the womb they really partook of' (p. 122). Ferenczi also notes that in fairy-tales our 'phantasies of omnipotence' (p. 126) come true - we may be immortal, possess magical powers, transform ourselves, and be protected from all threats.

Lothane notes that Ferenczi's (and Adler's) ideas compensated for 'Freud's last taboo, his denial of the real and causal role of power in humans relations' (1997, p. 26). Lothane discusses intra-psychic, family, political, organizational, cultural and spiritual aspects of power, noting that: 'In many religions the central attribute of the deity is limitless power [...] there is a reciprocal tendency to represent the parents as God-like and God as the heavenly all-loving father' (1997, p. 27).

In Paradise Lost, for example, John Milton refers to God as "th' Omnipotent" (2000, p. 4). Lothane describes 'collusion between the rulers and the ruled to result in mutually shared dreams, or delusions, of omnipotence, contrary to reason and the limitations imposed by reality' (1997, p. 28) - and he suggests that omnipotence:

is first attributed by the primitive man to nature itself, and, realizing his powerlessness, he seeks to propitiate nature as god or gods with the magic of incantations, prayers, and offerings? With the advent of the scientific view, intolerant of the prejudices of religion, powerless mankind has nobody left to 
propitiate except the new gods of the masses [...] in crowds, mobs, and masses we reach the level of mass neurosis, or mass madness, a folie à millions (1997, pp. 31-36)

The theme of collective identification with personifications of infinite power is central to the stream of critical thinking that considers the spiritual role of capital, brands and markets. Benjamin's fragment 'Capitalism as Religion', for example, is haunted by Nietzsche's understanding of the marketplace (and by Weber's analysis of the role of Protestantism in the development of capitalism):

One can behold in capitalism a religion [...] the attainment of a world of despair [...] Therein lies the historical enormity of capitalism: religion is no longer the reform of being, but rather its obliteration. [...] the Übermensch loses the apocalyptic "leap" [...] in the apparently continuous, but in the end rupturing, discontinuous intensification [...] a mental illness, which suits the capitalist epoch (2005 [1921], pp. 259-261)

Unlike Weber's measured style, Benjamin's fragment is mysterious and troubled (Löwy, 2009, p. 69). Benjamin is tormented by his understanding of capital as a sovereign materialisation of power, a merciless operating system that has engulfed humanity, an algorithm of ruin. Benjamin disjointedly traces the traumatic progression from paganism to theism to the global dominance of financial growth - an iron cage where we worship Power in the form of capital.

In his 'Powers' trilogy, Christian scholar Wink (1986) argued that 'The idea of living matter was simply economically inconvenient [...] if nature is dead then there are no restraints on exploiting it for profit' (p. 155). But he claimed that, 'The old gods of paganism are still very much alive, and that denial of this fact only guarantees their repression' (p. 108). Wink describes 'a society suicidally ravishing the environment' (p. 51) where 'those who are branded "insane" may in fact be too sensitive, too caring, too human' (p. 50). He identified as the root of unsustainability, 'societies or institutions or individuals [...] whose energies are bent on overpowering others' (p. 68).

Theologian Cox (1999, p. 20) notes 'the willed-but-not-yet-achieved omnipotence of The Market means that there is no conceivable limit to its inexorable ability to convert creation into commodities'. Tognato (2004) reviews the use of religious metaphors in public discourse about central banking, which he sees as a form of religion. Searles observes that (1972, p. 
369) 'We have worshipped technology, and our annual gross national product which epitomizes its growth, as a kind of god...' And Duivenvoorden (2013) criticizes what he sees as the false idol of economic growth, 'the mantra and god of governments around the world'.

In an analysis of the creation of money by private banks, Goodchild describes how 'debt money, the condition of possibility of the expansion of markets and production for the sake of profit, has indeed replaced the theoretical, practical, and social functions of God' (2013, pp. 53-54). And in her psychoanalysis of the 2008 financial crisis, Morante:

considers how omnipotence, illusion and the absence of the father/authority figure as the psychic representative of reality fostered a manic wave of rampant optimism, greed and over-confident investors [...] In the face of these real or perceived threats of destruction societies where materialistic values tend to prevail can no longer find, as in the past, an antidote in spirituality and religious belief. In this context it is not surprising that finance became an alternative "god" (2010, pp. 4-10)

Kozinets and Sherry note that 'capitalism flourished on the broken terrain of the isolated and empty self facing a frighteningly uncertain tomorrow, which it promised to make whole in the future, through the transformative power of fantasy' (2013, p. 245). Jhally (1989) notes that advertising stimulates fantasies of unlimited personal power, promising to reduce existential anxiety with magical feats of transformation, and by controlling the forces of nature.

Baudrillard (1993, 2012) describes how in the brandscape we lose touch with reality, shed our guilt about consumption, and merge with a gigantic fantasy of material-monetary progress (Lasn, 2000; Rutjens, van der Pligt, \& van Harreveld, 2009; Zepf, 2010). Brand personae are godlike in size, beauty and apparent intimacy, and their obvious unreality shields them from critical purchase, as they distract us from climate change, from ourselves, and from what corporations actually do (Goleman, 2010; Holt, 2002).

Holt (2006, p. 374) describes iconic brands as ideological parasites - e.g. in their use of the imagery and language of environmentalism and anti-corporate protest to increase corporate sales, profits and production - which in turn increases resource extraction, pollution, entropy and ecological disruption (Kitchen, 1994; Klein, 2010; Rees, 2012). Schwarzkopf's analysis of the development of 'consumer sovereignty' indicates that the putative attribution of 
sovereign power to 'consumers' is a symbolic gesture designed to flatter users and mask the sovereignty of a financial-political elite:

The reinvention of the consumer as a sovereign carries a theological baggage which does not only link consumption to individual salvation in an eschatological sense. The political theology that is hidden in consumer sovereignty theory predestines consumer-centred market democracies in an ecclesiological sense for absolute power. [...] Liberal economists needed this separation [of market choices from moral evaluation] in order to fantasize the consumer into existence as an omnipotent lawgiver to the market in the same way as early-modern political philosophers modelled the idea of the state as omnipotent lawgiver after the idea of an omnipotent God (2011b, pp. 109-116)

Murtola's analysis of Rev Billy's 'parodic over-identification' suggests that unmasking the ugly truths behind the beautiful façade of the brandscape is in itself not sufficient to elicit the radical change that is required to solve the environmental crisis. She claims that 'capitalism [...] appears today in many ways as a religion in its own right. [...] It should thus come as no surprise that anti-capitalist resistance today turns to theology for an effective counter-politics' (2012, p. 325).

\section{The emergence of Rev Billy from the madness of William Talen}

we need to perform this creative opposition. We haven't known how to oppose a culture led by Consumerism and apocalyptic Christianity - the twin fundamentalisms that overwhelm governments, silence creative culture or any non-commercial life (Billy, 2006, p. 56).

This case study is based on multiple sources of data: attending a performance/service of Rev Billy and the Stop Shopping Choir at the Casa bar and venue in Liverpool in July 2013 during their tour of the UK; meeting Rev Billy and members of the Church of Stop Shopping the following morning at the 'Institute for the Art and Practice of Dissent at Home' in Everton; conducting a transatlantic unstructured depth interview with Talen/Billy by Skype from his home in New York in August 2013; reviewing popular and academic literature on Reverend Billy; reading Talen's books; and analysing the Church of Stop Shopping website, blog, community emails and online archives including the documentary film What Would Jesus Buy? produced by Morgan Spurlock, and the video series Reverend Billy's Freakstorm. 
The author studied Rev Billy from 2010-2015. The above 'data' were fitted together with threads of theory stretching back over three decades of research into and bemusement with the psychopathology of power, using only the software that lives in the human brain (Gould, 2012). The 'unit of analysis' for this essay is what Lovejoy (1990) called the 'great chain of being', which I think of as the 'cosmic spine' or 'spine of Being' (Deleuze \& Guattari, 2012).

Taking the standard model of contemporary physics as one lens through which to examine the 'outside' of this cosmic spine, we encounter (and become lost in) intermeshed quarkic, atomic, molecular, cellular, personal, planetary, stellar, galactic, dark, holey and cosmic vertebrae. The 'insides' of the spine of Being may be experienced via animist, Hindu, Buddhist, gnostic, existential, Jungian, integral, Gaian and 'other' modalities of investigation (Szerszynski, 2010; Wilber, 1995).

By calibrating Rev Billy's story against the psychopathology of power, the essay explores how our (repressed) relationship with being and nothingness inadvertently spawns and organizes global unsustainability - and thus gain insight into how to make progress on the pressing issue of our time. The problem of unsustainability lurks between financio-political, physical and psycho-spiritual aspects of reality. Thus the essay is purposefully intra-faculty, based on the observation that university disciplines are often used as lairs where academics hide from the planetary tragedy which their work exacerbates or ignores, e.g. in amoral, mathematical and anti-ecological approaches to markets, economics, accounting and finance (Keen, 2001).

'I shudder to think when Reverend Billy started. I was so outside of time then, and I was out of place' (Talen, 2003, p. 27). William Talen created Reverend Billy as a way of freeing himself to speak his mind, to express his frustration at consumer culture, at financial corruption, and at the mess we are making of Earth. In the guise of Rev Billy, Bill Talen can relax, expand, preach, cajole, express his joie de vivre, and give voice to his ecologic laments and his political vision. Billy's televangelist charm softens Talen's eschatological prophecies and transformational dreams. 'The Rev' has a seriousness detector which reminds him to change gear when his sermons cross the line between satire and exhortation.

Born in 1950, in the mid-1990's Talen was manager of a theatre that Reverend Sidney Lanier had created in St. Clement's church in Hell's Kitchen, Manhattan. Living with his dog in a small room high in the church, Talen would sit at night in the darkened hall, in the 'comforting Dionysian stench of the great red chair', gaze through the stained glass windows 
'softly glowing from the heated hell of the city', and meditate on the state of the world (2003, p. 29):

We shop because we fear life. We shop because we want to banish from life something we identify with death, the unknown. It waits for us in that bright, unclaimed space. Of course, we are trained to think of what we can't know as a bad thing. Actually, it is the source of the brightness; it is why this space has no owner' (2003, p. xiv)

Lanier was the model for the troublesome and tormented former priest in The Night of the Iguana written by Lanier's friend and cousin Tennessee Williams. Lanier advised Talen to become 'a new kind of churchless minister. Sidney thought I should cast myself as a preacher who begins comically and then gets serious' (2003, p. 41). Talen 'bought a portable pulpit from the Christian supply store on Forty-third', donned a white tux, dog collar and Elvis hairstyle, walked to the Disney store, and began to preach (2003, p. 43):

Having a personal value system at consumer ground zero is ridiculous on its face. I could have been shouting on an interstate in the middle of Utah. [...] I was discovering that resisting consumerism is a lot trickier than just appearing in a public space and telling people to stop shopping. I had to induce some sort of counteryoga to reverse the locked-down totalizing eros of sales' (2003, p. 44).

Lone rants among the sidewalk preachers haranguing the sinners of Times Square gathered sparks of interest and support, and an activist-artistic community slowly developed:

Reverend Billy and the Stop Shopping Choir is a New York City based radical performance community, with 50 performing members and a congregation in the thousands. We are wild anti-consumerist gospel shouters and Earth loving urban activists $[\ldots]$ we are especially mindful of the extractive imperatives of global capital. [...] Our inspiration is the opening scene of Night of the Iguana, where the fulminating preacher drives his congregation out of the church and into the rain. At this time of the Earth's crisis, we must turn our institutions inside out and start over! (Billy, 2014)

Perucci describes how he collaborated with the Church of Stop Shopping in the act of exorcizing the cash register of a Starbucks café in California to protest Starbucks' supply chain and child labour practices. As a result, Talen was 'tried, convicted and sentenced [...] The City Attorney argued in her summation that the cash register and the "flow of business" 
are "things that are sacred"' (2008, p. 315). This is just one among dozens of arrests and legal challenges Talen has experienced as an activist.

Rev Billy and the Church have invented creative ways to protest specific practices of Disney, Victoria's Secret, Walmart, Monsanto, BP, JPMorgan and others. The Church's focus since 2013 has been to symbolically become or reanimate species, such as golden toads and honeybees, that are being harmed by climate change and pollution. 27 minutes into my Skype interview with Billy/Talen, we discussed the link between political activism and spirit:

Talen: $\quad[\ldots]$ generally our discovery in having and creating a post-religious church is that the language and the imagery still goes forward.

Freund: $\quad$ Yes, well, people are still spiritual beings even if they're not religious in their minds. They still - well, that's an assertion, but - I don't know what you think - but we're all, presumably, beings. Are we all spirits?

Talen: $\quad$ Yes. [...] I'll just put out this guess. We often think that the creation of community is the source of - not spirituality generally, all across the board for everybody - but for $u s$, we maintain a spirituality by being an activist group that is a community. Now, that is different than lots and lots of activist groups.

That's different than this other parallel thing that we are at the same, we're an activist group, we're an artistic group. So we're on concert stages and then we're in bank lobbies. We run the two parallels together, in time - through time.

But I would say that we have known for some time - we have people that we've been together since before 9/11, since the late 90s. We've had - what's the definition of community? - well, you go through time together, and you fall in love with each other, and then you break up, and you have children, and you die, and you gather around the body of the departed, and you're born, and you gather around the new-born.

A community goes through time together - and experiences life passage events together. That's an old fashioned idea of community, but that's what we think - that's what we're doing. And that, we find, creates a spiritual connection, and a courage. The things that flow from having a strong spiritual life that is tied to politics, and to a moral imperative.

The amazing thing is that you can do anything. You can go into the busiest museum in the world and you can exorcise a trillion dollar oil company that gives that museum money.

After discussing the role of spirit in anti-consumerist activism, Rev Billy opened up and expanded on his personal eschatology: 
[...] we have to democratize the financial institutions. We're now in such an emergency that we, basically have - we're in the OK Corral. We, basically, have a duel going on right now. One third of the parliament, I've been told, in the United Kingdom, one third of those guys have financial ties to the fossil fuel industries. [...] So there's a break in the democratisation, there's a break in the education, there's a break in the information flow. [...] The Earth is making this statement. The Earth is the main media right now. [...] The Earth is the main university. The Earth is the main source of health. The main source of birth and death. The Earth is our future. The Earth is our guide. [...] We have an extinction wave in the Earth that the human media's ignoring. So it's the part of climate change that you don't want to talk about because it's too awful, right? [...] consumerism is very powerful. It comes from thousands of marketing events every day. Coming into the individual psyche. [...] I think that the moment of a cultural break is imminent. I think it's going to happen. [...] We're battered by the Earth is trying to get through to us. But we have the corporations, they've pulled the wagons around any real discussion [...] It's all folded into normalcy. [...] We feel that, eventually, some breakthrough will take place. Because the weight of the incongruity, the nonsense of climate change, the ecocide of climate change is something that everybody's carrying around. They're carrying it around in everyday life. Every minute; we're carrying it around. The marketing's coming in our frontal lobe and saying it's all okay. But some part of us, inside, our spirit, some sort of inner conscience is inside of us saying, "You know what? It's not okay. It's not okay at all." Actually, the physical life of the Earth is altering at this time, accelerating in that alteration. It's veering off of its traditional trajectory, and it's not clear whether human beings will be a part of the future picture. [...] We have to represent that Earth conscience in this vapid pop world

A marketplace visionary, Talen has devoted his life to the Canute-like task of resisting the tide of marketing and financialization.

\section{Mad at the market}

a white water river of money that is imbued with its own intelligence and flows and flows through the world, following the path of least resistance, returning the most profit to the unseen master up there in the air, seated at a desk behind the glass that reflects back only clouds and sky (Billy, 2006, p. 195)

\section{Down to Earth}

The lone descent of Reverend Billy from the Episcopal church of St. Clement's into Times Square is reminiscent of Nietzsche's depiction of a madman entering the marketplace in The Gay Science (published in 1882): 
The Madman. - Have you not heard of that madman who lit a lantern in the bright morning hours, ran to the market place, and cried incessantly: "I seek God! I seek God!" - As many of those who did not believe in God were standing around just then, he provoked much laughter. Has he got lost? asked one. Did he lose his way like a child? asked another. Or is he hiding? Is he afraid of us? Has he gone on a voyage? emigrated? - Thus they yelled and laughed. (Nietzsche, 1974, p. 181)

The madman lights a lantern in the bright morning to highlight something in the market that is already in plain view. He feels compelled to highlight this event or process (or absence) because he believes the dominant social paradigm distracts people from the real meaning of modernity (Kilbourne, 2004). Nietzsche's scenario prefigures the Church of Stop Shopping's joyous, tragi-comic market interventions designed to interrupt the flow of capital, break the brand trance, highlight the real meaning of 'ad-verts', and turn our attention to Gaia (Latour, 2013).

The following publications help to contextualise Nietzsche's thinking about the spiritual importance of the market: Schopenhauer's The World as Will and Representation in 1818; Goethe's Faust Part 2 in 1831; Clausius' 'On the moving force of heat, and the laws regarding the nature of heat itself which are deducible therefrom' in 1850; Darwin's On the Origin of Species in 1859; Marx's Das Kapital volume 1 in 1867; Dostoyevski's The Idiot in 1869; then we have Freud's The Interpretation of Dreams and Veblen's The Theory of the Leisure Class in 1899; and in 1905 Einstein's 'Does the Inertia of a Body Depend Upon Its Energy Content?' and Weber's The Protestant Ethic and the Spirit of Capitalism.

This on-going rush of discoveries, and the technological explosion that accompanied it, accelerated the 'weakening of the explanatory powers of theology' (Schwarzkopf, 2011b, p. 109), and the erosion of the credibility of traditional religious narratives concerning how humans came to be and how the world works. Nietzsche's understanding of economics, biology and thermodynamics was sketchy, but he was acutely tuned to the psychological, cultural and spiritual implications of the physical and intellectual revolution that was occurring.

Nietzsche was fascinated by the interdisciplinary consequences of the traumatic and exhilarating rise of industrial power, and by the shift from the dominant idea of the world as God's creation towards the image of Earth, sun and cosmos as an infinite labyrinth of energies in which life appears to be a rare case of far-from-equilibrium organization and self- 
consciousness (Nietzsche, 1974, pp. 167-168; Prigogine, Nicolis, \& Babloyantz, 1972). Nietzsche was 'maddened' as much by casual atheist-materialism in which money and markets dominated human affairs as by the continuation of traditional religious beliefs in basically unchanged form. For Nietzsche, neither of these reactions was appropriate to the significance and the dangers of the new world that was being unveiled, invented and performed.

Like Nietzsche's madman, Rev Billy expresses Talen's anguish and frustration at the capitalist hyper-reality that he saw explode across Manhattan and across the face of planet Earth (Klein, 2010; Lasn, 2000). For Talen, the brandscape is blatantly intended to stimulate our greeds while distracting us from the accelerated ecological destruction it causes (Gross, 1997; Kaza, 2000; Loy, 1997). 'We have something in us that ad departments have an intense need for but which we ourselves have undervalued' (Talen, 2003, p. 127). Rev Billy's initial interventions were in one sense the act of despair of a lone madman, and in another sense represented a rare howl of sanity, of rational protest against a world gone mad, that he openly cared about.

Rev Billy laments the domination of global culture and economy by the fantasy of an infinitely-expanding market - that we have allowed ourselves to be controlled by a feedback cycle between our symbols of power (especially money) and our fantasies of omnipotence, exacerbated by financial PR, market research and the brandscape (Goldman \& Papson, 2006; Schwarzkopf, 2012). Talen is mad that by treating money as an end in itself, we have become trapped in a power-based logic of alienation from nature, from each other, and from ourselves (Eisenstein, 2007), and have become the tools of our own financial system. For Talen, the true psychopath of the marketplace is capital itself, and it is his vocation to protest against this process in the public domain (Bakan, 2005; Billy, 2012).

\section{Fantasies of an omnipotent market}

Nietzsche reinvented his marketplace scene in the Prologue of Thus Spoke Zarathustra (written in 1883-85). Zarathustra has spent a decade alone in the mountains when he descends to share the fruits of his enlightenment. He reaches a town and addresses a large (and mocking) crowd that is waiting to see a tightrope-walker: 
'Man is something that should be overcome [...] All creatures hitherto have created something beyond themselves: do you want to be the ebb of this great tide? [...] Once you were apes, and even now man is more of an ape than any ape. [...] I entreat you, my friends, remain true to the Earth, and do not believe those who speak to you of superterrestrial hopes!' [...]

all the people laughed at Zarathustra. But the tightrope-walker, who thought that the words applied to him, set to work. However, Zarathustra [...] spoke thus: 'Man is a rope stretched between animal and overman - a rope over an abyss. [...] What is great in man is that he is a bridge and not a goal' [...]

In the meantime, the tightrope-walker had emerged from a little door, and was proceeding across the rope, which was stretched between two towers and hung over the people and the market square. When he was halfway across the little door opened again, and a brightly-dressed fellow like a buffoon sprang out and rapidly followed him.

'Forward, lame-foot!' cried his frightful voice, 'go on, lazy-bones, intruder, paleface! - Lest I tickle you with my heel! What are you doing here between the towers? In the tower is the place for you, you should be locked up, you are blocking the way of a better man than you!' - With each word he came nearer the tightrope-walker: but when he was only a single pace behind him, there occurred the dreadful thing that silenced every mouth and fixed every eye: he uttered a cry like a devil and jumped over the tightrope-walker who was in his way.

The tightrope-walker, when he saw his rival thus triumph, lost his head and his footing, and fell in a vortex of arms and legs. The marketplace and the people flew apart in disorder, like a sea in a storm, especially where the body fell. Zarathustra, however, remained still, and the body fell close to him, badly injured and broken, but not yet dead. After a while, consciousness returned to the shattered man, and he saw Zarathustra kneeling beside him. 'What are you doing?' he said at last, 'I knew long ago that the Devil would trip me up. Now he's dragging me to Hell' (Nietzsche, 1969, pp. 41-48) Author's translation.

In Jung's Seminar on 'Zarathustra' (1998) many interpretations of this scene are discussed, including: whether the tightrope-walker represents the repressed shadow aspect of the person (p.59); or the energy from a dead god (p.35); or Nietzsche's ego inflation (p.35); or whether the tightrope-walker's plight is Nietzsche's prophecy of his own mental breakdown and death (p.60-61); whether the buffoon signifies Nietzsche's shadow jumping over him (p.60); or whether the buffoon personifies the resentment that Zarathustra's haughty speech inspires in the crowd, which makes them determined to thwart the effort of the tightrope-walker to cross the abyss between the two towers and become 'overman' (p.61). 
Similarly, Wolfe identifies both the crowd in the marketplace and the 'clown' with humanity in general, who mock and cause the death of those who dare to 'innovate' (1964, p. 547); whereas Hollingdale suggests the buffoon may represent Zarathustra, 'an unannounced attraction' (Nietzsche, 1969, p. 31).

The following alternative reading explores what the scene tells us about how to unblock the transition to sustainability. Zarathustra's descent from the mountains mirrors Nietzsche's life at that time, the years he spent as a lone thinker roaming the Alps. Zarathustra has been communing with wild animals and plants, with the Earth, sun and stars, enjoying the days and nights and the changing seasons, and enjoying the experience of just being, apart from the artefacts, diversions and strictures of society.

Like Nietzsche, Zarathustra had thoroughly divorced himself from human power structures. He makes a dramatic entry into the marketplace to deliver a prophecy and warning, which (with a crucial twist) is the eschatological message of market-square preachers throughout time: "Your worldview is wrong. Change your-selves radically, or you will suffer a fatal fall!" Zarathustra entreats us to remain true to the Earth - indicating that what might save us is to regain appreciation of the beauty of the Earth. Nietzsche was aware that as well as loving the Earth, parts of us also fear and resent aspects of Earthbound being.

In the form of our mother, the Earth gives birth to us; but we never leave the body of Gaia; we spend our days living, eating and breathing within her. Some aspects of human being resent that dependence, resent the fact that our bodies will one day be swallowed up by Earth, that we will disintegrate, be digested, recycled and dispersed again within her flows (Becker, 1997; Koole \& Van den Berg, 2004). As suggested by Sherry, the beauty of these processes may be apparent to our field-like transpersonal selves, which see that our energies and actions are part of the tree of life, and the wider cosmos; but the thought of finitude also represents an emotional threat to the narrower reality of the 'I' (Jung, 1978; Wilber, 1995).

For Nietzsche, modernity was characterised by descent of the imagined locus of Power from the heavens into the market and the individual (Edinger, 1990; Schwarzkopf, 2011a). Nietzsche sees the worship of an ever-more powerful world market as a misguided response to the relative loss of power of traditional deities. The tightrope-walker in the scene, who thought that Zarathustra's words applied to him, could represent that aspect of ourselves that is trying to evolve; trying to develop new ways of being and working - trying to 'build a 
house for the overman and prepare earth, animals and plants for him' (Nietzsche, 1969, p. 44); trying to reconnect with the living Earth.

In the middle of this difficult collective undertaking, the tightrope-walker is cruelly harassed and overleapt by a devilish buffoon, who precipitates the fatal fall, then vanishes. It is instructive to conceive of this nasty buffoon as our (collective) will-to-omnipotence. In Faustian terms, Mephistopheles (a devilish buffoon indeed) is that which offers you unlimited wish-fulfilment, or omnipotence (Goethe, 2001; Monbiot, 2007) - but omnipotence is unachievable. The more we industrially dominate and consume Gaia, the closer we get to ecological collapse. That is not surprising when one considers that GDP is correlated to ecological impact (Georgescu-Roegen, 1971; Jackson, 2009).

The development of the Earth since Nietzsche's time seems to bear out his fears of will-topower run amok, including the creation of the Federal Reserve System; the Great War; the Wall Street Crash; the Great Depression; Hitler, the Holocaust, Hiroshima; Stalin, Mao; proliferation of nuclear weapons; population explosion; globalization of consumerism; Ghawar oil field; endless financial growth as humanity's supreme goal; organized denial of global warming; Commodity Futures Modernization Act; destruction of the World Trade Centre; financial crises; mass species extinction; tar sands, fracking, methane hydrates; atmospheric $\mathrm{CO}_{2}$ exceeding 400ppm.

So far I have stressed similarities between Rev Billy and Zarathustra - but there are also differences - not least the fact that Nietzsche went insane, whereas Talen is (currently) sane. Talen is transparently political, and envisions the world as a decentralised eco-communitarian carnival of joy (Billy, 2012; Friedrichs, 2010; Kozinets \& Sherry, 2013; Stoekl, 2007); whereas Nietzsche claimed to be anti-political. Nietzsche wrote in riddles, always seeking the line of ambiguity between alternative interpretations, adopting apparently contradictory perspectives, and inviting confusion and conflict over his ideas - such as whether the will to power is a glorification or a critique of human yearning for omnipotence (Kaufmann, 1974).

Nietzsche's carefully-designed ambiguity applies to Zarathustra's marketplace. For some commentators, the tightrope-walker would represent humanity's righteous and rational struggle for increasing power and prosperity. The far tower in the allegory represents the desired end-state, be that a world where we intelligently change economy and culture to reduce our ecological impact (International Energy Agency, 2013; Meadows, Randers, \& Meadows, 2006); a world where everyone has cars and holidays in Disneyland; a world 
where we terraform other planets and colonize the galaxy; or even the literal occurrence of the scenes described in the Book of Revelations (S. Brown, Bell, \& Carson, 1996; Edinger, 2002; Hill, 2004; Monbiot, 2004).

For each dreamer, the devilish buffoon who upsets the tightrope-walker represents their archdemon, their Other, whoever they see as thwarting their efforts to realise their dream. Responses to Zarathustra's market scene bring out the heroes and villains of each person's worldview, and reveal what matters to them. Land described 'overman' as 'a planetary artistic experiment about which nothing can be decided in advance' (1992, p. 15). But by describing us as a bridge, Nietzsche pointed out that for involution/evolution to continue, we must avoid the fatal potential of collective fantasies of omnipotence or will to power run amok (Nietzsche, 1969). Zarathustra's marketplace helps us to appreciate that alternative worldviews are not equal in terms of their rationality, their beauty, or in terms of whether they are physically sustainable.

\section{Unconclusion}

We have killed trees like no other living thing. [...] "Scientific analysis points, curiously, toward the need for a quasi-religious transformation of contemporary cultures" [...] Sandy grew to a thousand miles wide and turned left to enter the big city like the vengeful resurrection of the world's dead trees. In our Forest Faith we believe that there are forests inside the storms! The writhing beauty of the roots, the pulsing smiles under the bark pushing water up into the leaves where the green miracle of photosynthesis takes place, the gentle raking of the sky's invisible gasses - all this is inside the storm that rips off our roofs. (Billy, 2012, pp. 49-51)

A psychodynamic analysis of power suggests that the transition to sustainability is blocked by our (idolatrous) 'worship' of an infinitely-expanding marketplace - our false belief that the invisible hands or brain of this Market God will save us. This helps to answer McDonagh and Prothero's question concerning why we persist with a market system that is blatantly destroying the conditions that sustain it.

The global financial system commands our respect because its objective of limitless growth defies rationality. The audacity of this physically-impossible goal, and the contempt of the financial operating system for the physical state of the planet may suggest to an uncritical 
observer that capital (i.e. accumulated symbolic human power) is not subject to the laws of nature.

This (false) conclusion flatters our collective ego. The supernatural claims of political, financial and business leaders that more economic growth will improve matters give us a sort of 'immortality boost', an everyday promise of human exceptionalism. We kid ourselves that we own the planet - that we are able to manage or engineer Gaia (Lovelock, 2006; Lynas, 2011). The prospect of being saved by yet more growth appeals to our longing for what the Grand Inquisitor calls 'miracle, mystery and authority' (Dostoevsky, 1930, p. 22).

Extravagant claims made by 'authorities' play to the common desire 'to believe in something significantly more powerful and extraordinary than the self - a need to transcend existence as a mere biological being coping with the everyday world' (Belk, Wallendorf, \& Sherry, 1989, p. 2). The word 'need' in this quotation dignifies what Searles argues is a delusion based on fear and loathing of reality - can one need something that is impossible? By contrast, Sherry (2013, p. 218) describes inter-being, or liberation from will-to-omnipotence: 'synthesis of the dialectic of immanence and transcendence that results in our transfiguration [...] an integrative, epiphanic energy reflecting the connection and identity of beings'.

Our problem is not real powerlessness - we are not individually or collectively powerless. Our problem is our fear of powerlessness, reality and death, which emerges as the ego's petulant desire to dominate nature. Fear is not our only feeling towards nature - we also genuinely love and respect nature - but our innate reverence for Gaia is blocked by financialization, by most corporate marketing, and by the collusion of so-called left and right wings of an illusory political spectrum that refuses to question why we need financial growth (E. H. Brown, 2010; Shearman \& Smith, 2007).

Our problem is not power, it is our conception of power as an end in itself. As a system goal, power is insatiable, addictive and self-destructive (Freund \& Jacobi, 2013) - it is a physical, moral and spiritual mistake. Power must be used for a sustainable purpose, to achieve something beyond itself, and beyond the interests of that which wields it. The purpose of organizations and nations is not financial - it is to focus us on the sustained wellbeing of Gaia, including ourselves (Latour, 1993; Seed, Macy, Fleming, \& Naess, 2007).

Profit-oriented banks create almost all the money in the global economy by loaning it into existence ex nihilo as interest-bearing debt. The eco-social consequences of this ever-growing 
debt bubble are severe (E. H. Brown, 2010; Lietaer, Arnsperger, Goerner, \& Brunnhuber, 2012). As the threat of ecological collapse grows, we floor the financial growth pedal everharder to try to save ourselves. In system terms, this is a positive feedback cycle - which tends to lead to system instability and collapse. It is a vicious cycle, a hiding to nothing even for the rich.

We must redesign our monetary, financial and political systems with the achievable and homeostatic goal of ecological sustainability. This objective lies outside ourselves, is real, and is not self-defeating. In system terms, making ecological sustainability our goal forms a self-correcting feedback loop where divergence from the goal automatically triggers corrective action (Zovanyi, 2013).

Rev Billy would like delight to recur for another eon at least. He sees us as seven billion drops of potential, of change, of creativity, who can rationally and emotionally persuade ourselves to make a great transition, to fall in love with reality - to fight for life, in solidarity with Earthbound beings of the future: 'Without them, this Earth would have been an unlivable place like so many other planets, and we would not have come into existence' (Morgan, 2009, p. 692).

It is a paradox of power that green warriors such as Rev Billy lack structural power, and often have a deep aversion to the addictive qualities of power (Almond, 1997). Another paradox of our situation is that the power of positive thinking is essential, but is also deadly unless it is physically-realistic positive thinking (Hamilton, 2010). The rhetoric of sustainability is now integrated into the communications of oil majors, coal-mining firms, corporations, banks and governments worldwide. But this symbolic victory has been accompanied by a devastating physical assault on Gaia in the form of Gargantuan extraction, consumption, disposal and waste (Becker, 1997; Dickinson, 2009; Monbiot, 2009).

It is up to us to break the game-theoretic deadlock of organizational power struggles, and 'bring about a society in which striving for sustainability is the norm' (Martin, 2012). The creative spirit of Rev Billy and the Church of Stop Shopping is a power that green activists around the world can use as they work towards sustainability. Practical priorities include decarbonization (International Energy Agency, 2013); a global carbon fee charged at mines and ports of entry that is rebated directly to citizens (Hansen, 2014); planned degrowth (Zovanyi, 2013); and redesigning the monetary and financial system to be simple, stable and durable (Greenham, Ryan-Collins, Werner, \& Jackson, 2012; Heinberg, 2011). 
Nietzsche saw the cosmos as 'a monster of energy' (1968, p. 550), and described life as something 'late, rare, accidental, that we perceive only on the crust of the earth' $(1974, \mathrm{p}$. 167). He did not want us to fear our isolation in space, but to experience it as ourselves, as epiphany, as mysterium tremendum (Otto, 1958). Nietzsche's joyous science points out that the energy from which we sprang has, as us, become aware of itself. As Lawrence (1932, p. 223) observed: 'I am part of the sun as my eye is part of me'.

Our joy is the joy of the 4-billion year-old 'person' Gaia. It is the joy of the cosmos as it spontaneously organizes itself, and reflects what in Hinduism is called sat-chit-änanda: being-consciousness-bliss. Thinking clearly about the Earth in space and time opens us to a revelation much greater than any fantasy of omnipotence - the reality of emerging in an infinite spirit of energy that delights in being alive. 
References

Almond, R. (1997). Omnipotence and power. In C. S. Ellman \& J. Reppen (Eds.), Omnipotent Fantasies and the Vulnerable Self (pp. 1-37). Northvale, NJ: Jason Aronson.

Arndt, J., \& Vess, M. (2008). Tales from existential oceans: Terror management theory and how the awareness of our mortality affects us all. Social and Personality Psychology Compass, 2(2), 909-928. doi: 10.1111/j.1751-9004.2008.00079.x

Bakan, J. (2005). The Corporation: The Pathological Pursuit of Profit and Power. London: Robinson. Baudrillard, J. (1993). Symbolic Exchange and Death (I. H. Grant, Trans.). London: Sage.

Baudrillard, J. (2012). The Consumer Society: Myths and Structures (C. Turner, Trans.). London: SAGE. Becker, E. (1997). The Denial of Death. New York: Free Press.

Beddoe, R., Costanza, R., Farley, J., Garza, E., Kent, J., Kubiszewski, I., et al. (2009). Overcoming systemic roadblocks to sustainability: The evolutionary redesign of worldviews, institutions, and technologies. Proceedings of the National Academy of Sciences, 106(8), 2483-2489. doi: 10.1073/pnas.0812570106

Belk, R. W., Wallendorf, M., \& Sherry, J. F., Jr. (1989). The Sacred and the Profane in Consumer Behavior: Theodicy on the Odyssey. Journal of Consumer Research, 16(1), 1-38. doi: $10.2307 / 2489299$

Benjamin, W. (2005 [1921]). Capitalism as Religion (C. Kautzer, Trans.). In E. Mendieta (Ed.), The Frankfurt School on Religion: Key Writings by the Major Thinkers (pp. 259-262). New York: Routledge.

Billy, R. (2006). What Would Jesus Buy?: Fabulous Prayers in the Face of the Shopocalypse. New York: Public Affairs.

Billy, R. (2012). THE END OF THE WORLD. New York: O/R Books.

Billy, R. (2014). Reverend Billy \& the Church of Stop Shopping - About Us Retrieved 3rd June 2014, from http://www.revbilly.com/about-us

Brown, E. H. (2010). Web of Debt: The Shocking Truth about Our Money System and How We Can Break Free (4th ed.). Baton Rouge: Third Millennium Press.

Brown, S., Bell, J., \& Carson, D. (1996). Marketing Apocalypse: Eschatology, Escapology and the Illusion of the End. London: Routledge.

Butler, J. (1997). The Psychic Life of Power: Theories in Subjection. Stanford: Stanford University Press.

Chakrabarty, D. (2009). The Climate of History: Four Theses. Critical Inquiry, 35(2), 197-222. doi: $10.1086 / 596640$

Cox, H. (1999). The market as God: Living in the new dispensation. The Atlantic Monthly, 283(3), 1823.

Crist, E. (2013). On the poverty of our nomenclature. Environmental Humanities, 3, 129-147.

Daly, H. E. (2014). From Uneconomic Growth to a Steady-State Economy. Cheltenham: Edward Elgar Publishing.

de Vries, M. F. R. K. (1991). Whatever happened to the philosopher-king? The leader's addiction to power. Journal of Management Studies, 28(4), 339-351. doi: 10.1111/j.14676486.1991.tb00285.x

Deleuze, G., \& Guattari, F. (2012). A thousand plateaus: Capitalism and schizophrenia (B. Massumi, Trans.). London: Continuum.

Dickinson, J. L. (2009). The people paradox: Self-esteem striving, immortality ideologies, and human response to climate change. Ecology and Society, 14(1), 34.

Dodds, J. (2011). Psychoanalysis and Ecology at the Edge of Chaos: Complexity theory, Deleuze/Guattari and Psychoanalysis for a Climate in Crisis. London: Routledge.

Dostoevsky, F. M. (1930). The Grand Inquisitor (S. S. Koteliansky, Trans.). London: Elkin Mathews and Marrot. 
Duivenvoorden, C. (2013). It's Time to Turn Away From the God of Economic Growth Retrieved 17th October 2014, from http://www.huffingtonpost.ca/carl-duivenvoorden/the-downside-ofeconomic-growth b 3179374.html

Edinger, E. F. (1990). Goethe's Faust: Notes for a Jungian commentary. Toronto: Inner City Books.

Edinger, E. F. (2002). Archetype of the Apocalypse: Divine Vengeance, Terrorism, and the End of the World: Open Court.

Eisenstein, C. (2007). The Ascent of Humanity. Harrisburg: Panenthea Press.

Ellman, C. S., \& Reppen, J. (1997). Omnipotent Fantasies and the Vulnerable Self. Northvale, New Jersey: Jason Aronson.

Ferenczi, S. (1925). Stages in the development of the sense of reality (E. Jones, Trans.) An outline of psychoanalysis (pp. 108-127): Modern Library.

Fisk, G. (1973). Criteria for a theory of responsible consumption. Journal of Marketing, 37(2), 24-31.

Freud, S. (1999). Animism, Magic and the Omnipotence of Thoughts (J. Strachey, Trans.) Totem and Taboo: Some Points of Agreement Between the Mental Lives of Savages and Neurotics (International Library of Psychology) (Vol. IX, pp. 75-99). London: Routledge.

Freund, J., \& Jacobi, E. S. (2013). Revenge of the brand monsters: How Goldman Sachs' doppelgänger turned monstrous. Journal of Marketing Management, 29(1-2), 175-194. doi: $10.1080 / 0267257 \times .2013 .764347$

Friedrichs, J. (2010). Global energy crunch: How different parts of the world would react to a peak oil scenario. Energy Policy, 38(8), 4562-4569.

Georgescu-Roegen, N. (1971). The Entropy Law and the Economic Process. Cambridge: Harvard University Press.

Goethe, J. W. v. (2001). Faust: A Tragedy (W. Arndt, Trans. Norton Second Critical ed.). New York: W.W. Norton \& Company.

Goldman, R., \& Papson, S. (2006). Capital's brandscapes. Journal of Consumer Culture, 6(3), 327-353. doi: $10.1177 / 1469540506068682$

Goleman, D. (2010). Ecological Intelligence: The Coming Age of Radical Transparency. London: Penguin.

Goodchild, P. (2012). What is Wrong with the Global Financial System? Journal of Interdisciplinary Economics, 24(1), 7-28. doi: 10.1177/0260107912471457

Goodchild, P. (2013). Exposing Mammon: Devotion to Money in a Market Society. Dialog, 52(1), 4757. doi: 10.1111/dial.12009

Gould, S. J. (2012). The emergence of Consumer Introspection Theory (CIT): Introduction to a JBR special issue. Journal of Business Research, 65(4), 453-460. doi: http://dx.doi.org/10.1016/i.jbusres.2011.02.010

Greenham, T., Ryan-Collins, J., Werner, R., \& Jackson, A. (2012). Where Does Money Come From?: A Guide to the UK Monetary and Banking System. London: The New Economics Foundation.

Gross, R. M. (1997). Toward a Buddhist Environmental Ethic. Journal of the American Academy of Religion, 65(2), 333-353. doi: 10.2307/1465768

Hamilton, C. (2010). Requiem for a Species: Why we Resist the Truth about Climate Change. London: Earthscan.

Hanh, T. N. (2008). The Art of Power. New York: HarperOne.

Hanh, T. N. (2013). A Love Letter to the Earth. Berekley, CA: Parallax Press.

Hansen, J. (2009). Storms of my Grandchildren: The Truth about the Coming Climate Catastrophe and our Last Chance to Save Humanity. London: Blooomsbury.

Hansen, J. (2014). lowa Roots: Speaking Truth to Power Retrieved 16th October 2014, from http://www.columbia.edu/ jeh1/mailings/2014/20141012 lowaRoots2.pdf

Harvey, G. (2006). ANIMALS, ANIMISTS, AND ACADEMICS. Zygon ${ }^{\circledR}$, 41(1), 9-20. doi: 10.1111/j.14679744.2006.00723.x

Heinberg, R. (2007). The Party's Over: Oil, War and the Fate of Industrial Societies (Second ed.). Forest Row: Clairview Books. 
Jackson, T. (2009). Prosperity without Growth: Economics for a Finite Planet. London: Earthscan.

Jhally, S. (1989). Advertising as religion: The dialectic of technology and magic. In I. H. Angus \& S. Jhally (Eds.), Cultural Politics in Contemporary America (pp. 217-229). New York: Routledge.

Jung, C. G. (1966). Two Essays on Analytical Psychology (R. F. C. Hull, Trans. Second ed.). Princeton, N.J.: Princeton University Press.

Jung, C. G. (1978). Aion: Researches into the Phenomenology of the Self (R. F. C. Hull, Trans. Second ed.). Princeton, N.J.: Princeton University Press.

Jung, C. G. (1998). Jung's Seminar on Nietzsche's Zarathustra (Abridged ed.). Princeton, NJ: Princeton University Press.

Kaufmann, W. (1974). Nietzsche: Philosopher, Psychologist, Antichrist (4th ed.). Princeton, NJ: Princeton University Press.

Kaza, S. (2000). Overcoming the Grip of Consumerism. Buddhist-Christian Studies, 20, 23-42. doi: $10.2307 / 1390317$

Keen, S. (2001). Debunking economics - The Naked Emporer Dethroned? (Revised and Expanded Edition ed.). London: Zed Books.

Kilbourne, W. E. (2004). Sustainable communication and the dominant social paradigm: Can they be integrated? Marketing Theory, 4(3), 187-208.

Kitchen, P. J. (1994). The Marketing Communications Revolution - A Leviathan Unveiled? Marketing Intelligence \& Planning, 12(2), 19-25.

Klein, N. (2010). No logo (10th Anniversary ed.). London: Fourth Estate.

Koole, S. L., \& Van den Berg, A. E. (2004). Paradise lost and reclaimed: An existential motives analysis of human-nature relations. In J. Greenberg, S. L. Koole \& T. Pyszczynski (Eds.), Handbook of experimental existential psychology (pp. 86-103). New York: Guildford Press.

Koole, S. L., \& Van den Berg, A. E. (2005). Lost in the wilderness: Terror management, action orientation, and nature evaluation. Journal of personality and social psychology, 88(6), 10141028.

Kozinets, R. V., \& Sherry, J. F., Jr. (2013). The Autothemataludicization Challenge: Spiritualizing Consumer Culture Through Playful Communal Co-Creation. In D. Rinallo, L. M. Scott \& P. Maclaran (Eds.), Consumption and Spirituality (pp. 242-266). London: Routledge.

Land, N. (1992). The thirst for annihilation: Georges Bataille and virulent nihilism (an essay in atheistic religion). London: Routledge.

Lasn, K. (2000). Culture Jam: How to Reverse America's Suicidal Consumer Binge - and Why We Must. New York: Quill. 
Latour, B. (1993). We have never been modern (C. Porter, Trans.). Cambridge, Massachusetts: Harvard University Press.

Latour, B. (2013). Facing Gaia: Six lectures on the political theology of nature. Gifford Lectures on Natural Religion, Edinburgh, 18th-28th of February 2013. Edinburgh: The University of Edinburgh.

Lawrence, D. H. (1932). Apocalypse. London: Martin Secker.

Lietaer, B., Arnsperger, C., Goerner, S., \& Brunnhuber, S. (2012). Money and Sustainability: The Missing Link. Axminster: The Club of Rome - EU Chapter (to Finance Watch and the World Business Academy).

Lothane, Z. (1997). Omnipotence, or the Delusional Aspect of Ideology, in Relation to Love, Power, and Group Dynamics. The American Journal of Psychoanalysis, 57(1), 25-46. doi: 10.1023/a:1024622504975

Lovejoy, A. O. (1990). The great chain of being: A study of the history of an idea. Cambridge: Harvard University Press.

Lovelock, J. (2006). The revenge of Gaia: Why the earth is fighting back - and how we can still save humanity. London: Allen Lane.

Löwy, M. (2009). Capitalism as Religion: Walter Benjamin and Max Weber. Historical Materialism, $17(1), 60-73$.

Loy, D. R. (1997). The Religion of the Market. Journal of the American Academy of Religion, 65(2), 275-290. doi: 10.2307/1465766

Lynas, M. (2011). The God Species. London: Fourth Estate.

Martin, D. (2012). Life or death marketing. Tenured Professors' Installation Lectures at Aalto University 12.12.2012 Retrieved 10th October 2014, from http://www.youtube.com/watch?v=inirmUnl-Gw

Mascaró, J. (2004). The Dhammapada: Penguin UK.

McDonagh, P., \& Prothero, A. (2014). Sustainability marketing research: past, present and future. Journal of Marketing Management, 30(11-12), 1186-1219. doi: 10.1080/0267257x.2014.943263

Meadows, D. H., Randers, J., \& Meadows, D. L. (2006). The limits to growth: The 30-year update. London: Earthscan.

Milton, J. (2000). Paradise Lost. London: Penguin Classics.

Monbiot, G. (2004). Apocalypse Please Retrieved 7th June 2014, from http://www.monbiot.com/2004/04/20/apocalypse-please/

Monbiot, G. (2007). Heat: How we can stop the planet burning. London: Penguin.

Monbiot, G. (2009, 2nd November). Death Denial, The Guardian.

Morante, F. (2010). Omnipotence, retreat from reality and finance: psychoanalytic reflections on the 2008 financial crisis. International Journal of Applied Psychoanalytic Studies, 7(1), 4-21. doi: 10.1002/aps.232

Morgan, D. R. (2009). World on fire: two scenarios of the destruction of human civilization and possible extinction of the human race. Futures, 41(10), 683-693. doi: http://dx.doi.org/10.1016/j.futures.2009.07.011

Murtola, A.-M. (2012). Materialist theology and anti-capitalist resistance, or, 'What would Jesus buy?'. Organization, 19(3), 325-344. doi: 10.1177/1350508412437278

Nietzsche, F. W. (1968). The Will to Power (W. Kaufmann \& R. J. Hollingdale, Trans.). New York: Vintage Books.

Nietzsche, F. W. (1969). Thus Spoke Zarathustra: A book for everyone and no one (R. J. Hollingdale, Trans.). London Penguin.

Nietzsche, F. W. (1974). The gay science: With a prelude in rhymes and an appendix of songs (W. Kaufmann, Trans.). New York: Vintage.

Otto, R. (1958). The idea of the holy: An inquiry into the non-rational factor in the idea of the divine and its relation to the rational (J. W. Harvey, Trans.). London: Oxford University Press. 
Perucci, T. (2008). Guilty as Sin: The Trial of Reverend Billy and the Exorcism of the Sacred Cash Register. Text and Performance Quarterly, 28(3), 315-329. doi: 10.1080/10462930802107936

Prigogine, L., Nicolis, G., \& Babloyantz, A. (1972). Thermodynamics of evolution. Physics Today, 25, 38.

Rank, O. (2002). Psychology and the soul: A study of the origin, conceptual evolution, and nature of the soul (G. C. Richter \& E. J. Lieberman, Trans.). Baltimore: Johns Hopkins University Press.

Rees, W. E. (2012). Cities as Dissipative Structures: Global Change and the Vulnerability of Urban Civilization. In M. P. Weinstein \& R. E. Turner (Eds.), Sustainability Science (pp. 247-273): Springer New York.

Rifkin, J., \& Howard, T. (1980). Entropy: A New World View. New York: Viking.

Roszak, T., Gomes, M. E., \& Kanner, A. D. (1995). Ecopsychology: Restoring the earth, healing the mind. San Francisco: Sierra Club Books.

Rust, M.-J. (2008). Climate on the couch: unconscious processes in relation to our environmental crisis. Psychotherapy and Politics International, 6(3), 157-170. doi: 10.1002/ppi.174

Rutjens, B. T., van der Pligt, J., \& van Harreveld, F. (2009). Things Will Get Better: The AnxietyBuffering Qualities of Progressive Hope. Personality and Social Psychology Bulletin, 35(5), 535-543. doi: 10.1177/0146167208331252

Ryland, E. (2000). Gaia Rising. Organization \& Environment, 13(4), 381.

Schiller, F. (1785). Ode to Joy Retrieved 12th January 2015, from http://en.wikisource.org/wiki/Ode to Joy

Schumacher, E. F. (2011). Small is beautiful: Economics as if people mattered. London: Vintage.

Schwarzkopf, S. (2011a). The Consumer as "Voter," "Judge," and "Jury": Historical Origins and Political Consequences of a Marketing Myth. Journal of Macromarketing, 31(1), 8-18. doi: $10.1177 / 0276146710378168$

Schwarzkopf, S. (2011b). The Political Theology of Consumer Sovereignty: Towards an Ontology of Consumer Society. Theory, Culture \& Society, 28(3), 106-129. doi: 10.1177/0263276410396912

Schwarzkopf, S. (2012). The market order as metaphysical loot: Theology and the contested legitimacy of consumer capitalism. Organization, 19(3), 281-297. doi: $10.1177 / 1350508412437618$

Searles, H. F. (1972). Unconscious processes in relation to the environmental crisis. Psychoanalytic Review, 59(3), 361-374.

Seed, J., Macy, J., Fleming, P., \& Naess, A. (2007). Thinking Like a Mountain: Towards a Council of All Beings. Gabriola Island, B.C.: New Catalyst Books.

Shearman, D. J., \& Smith, J. W. (2007). The climate change challenge and the failure of democracy: Greenwood Publishing Group.

Sheets-Johnstone, M. (2003). Death and immortality ideologies in Western philosophy. Continental Philosophy Review, 36(3), 235-262. doi: 10.1023/B:MAW0.0000003937.47171.a9

Sherry, J. F., Jr. (2000). Distraction, destruction, deliverance: the presence of mindscape in marketing's new millennium. Marketing Intelligence \& Planning, 18(6/7), 328-336. doi: doi:10.1108/02634500010348914

Sherry, J. F., Jr. (2001). Sometimes Leaven with Levin: A Tribute to Sidney J. Levy on the Occasion of His Receiving the Converse Award. In A. Griffin \& J. Ness (Eds.), The Fifteenth Paul D. Converse Symposium (pp. 54-63). Chicago: American Marketing Association.

Sherry, J. F., Jr. (2013). Reflections of a Scape Artist: Discerning Scapus in Contemporary Worlds. In D. Rinallo, L. M. Scott \& P. Maclaran (Eds.), Consumption and spirituality. London: Routledge.

Sievers, B. (1999). Psychotic Organization as a Metaphoric Frame for the Socioanalysis of Organizational and Interorganizational Dynamics. Administration \& Society, 31(5), 588-615. doi: 10.1177/00953999922019256 
Stoekl, A. (2007). Bataille's Peak: Energy, Religion, and Postsustainability. Minneapolis: University of Minnesota Press.

Stutz, J. (2010). The three-front war: Pursuing sustainability in a world shaped by explosive growth. Sustainability: Science, Practice, \& Policy, 6(2), 49-59.

Szerszynski, B. (2010). Reading and Writing the Weather: Climate Technics and the Moment of Responsibility. Theory, Culture \& Society, 27(2-3), 9-30. doi: 10.1177/0263276409361915

Talen, B. (2003). What should I do if Reverend Billy is in my store? New York: New Press.

Talen, B. (2012). Reverend Billy Freakstorm: The Consumers Consumed The Consumer Retrieved 30th September 2014, from http://www.youtube.com/watch?v=DsJp4aLI9PY

Taylor, B. (2010). Dark green religion: nature spirituality and the planetary future. Berkeley: University of California Press.

Tognato, C. (2004). In the name of money: Central banking as a secular religion. Manuel Ancizar lecture.

Vidal, J. (2014, 27th December). Pope Francis's edict on climate change will anger deniers and US churches, The Guardian. Retrieved from http://www.theguardian.com/world/2014/dec/27/pope-francis-edict-climate-change-usrightwing

Wilber, K. (1995). Sex, ecology, spirituality: The spirit of evolution. Boston: Shambhala.

Wilber, K. (1996). The Atman project: A transpersonal view of human development (Second ed.). Wheaton, Illinois: Quest Books.

Wink, W. (1986). Unmasking the powers: The invisible forces that determine human existence (Vol. 2). Philadelphia: Fortress Press.

Wolfe, P. (1964). Image and Meaning in Also sprach Zarathustra. MLN, 79(5), 546-552. doi: $10.2307 / 3042700$

Zepf, S. (2010). Consumerism and identity: Some psychoanalytical considerations. International Forum of Psychoanalysis, 19, 144-154.

Zovanyi, G. (2013). The No-growth Imperative: Creating Sustainable Communities Under Ecological Limits to Growth. London: Routledge. 